\title{
Development of Students' Historical Knowledge through Infographics of National Heroes
}

\author{
Syaiful Amin ${ }^{1}$, Atno $^{2}$, Ganda Febri Kurniawan ${ }^{3}$ \\ Universitas Negeri Semarang \\ syaifulamin@mail.unnes.ac.id ${ }^{1}$, atnosejarah@mail.unnes.ac.id², gandafk4@gmail.com³
}

\begin{abstract}
In the online era, the role of the media in facilitating learning history is very important. Learning in the online era is considered to return to conventional models that lack the use of innovative media. This study aims to analyze the development of historical knowledge of students in learning history using national hero infographic. This study uses qualitative methods with descriptive designs. The data source of this research came from teachers and students. Data were collected using in-depth interview and observation techniques. Data analysis uses an interactive model. The results study are: 1) students' knowledge about national heroes develops after learning using the national hero infographic; 2) the unit of knowledge development lies in the way students identify heroes, understand the role of heroes, and the reflective attitude of students after learning with national hero infographics; and 3) factors that play a role in developing students' historical knowledge about heroism are ideology and social context. The conclusion of this research is that relevant national hero infographics are used in the effort to develop students 'heroes' knowledge in the history class.
\end{abstract}

Keywords: Development, Knowledge, Infographics, National Heroes.

\section{Introduction}

One of the problems with education online, is the lack of use of innovative media in learning. In addition, learning is also more often done by the lecture method rather than interactive discussion [1]. This problem is reminiscent of the days before the implementation of K13 (Curriculum 2013), when criticism of conventional media was rife. Technological progress, with the application of online media, should be a moment in the development of more radical learning, especially for social science learning, one of which is in the field of history [2]. Learning history has the aim to develop students' historical knowledge, which includes awareness and ability to reflect on the conditions experienced by students. Important historical awareness is fostered to create dynamic reasoning in students, through historical awareness [3], Anderson [4] illustrates that Indonesia is a strong community with a broad imagination of nationalism stretching from traditional to modern times. The ability of reflection for Kochhar [5] is an essential skill in fostering citizens, history is a mirror that contains a number of experiences of a nation. History becomes knowledge that can measure and predict people's lives in the future. From this explanation, history in the current era cannot be taught with conventional media, especially in the online period, it is needed an innovative media that contains information and is interesting for students learning history [6]. That is, the media needs to contain provocative things to teach students about the historical experience of events, figures and historical places / buildings. 
National hero infographics are important to use, remembering that students need something concrete in learning [7], [8]. The combination of graphics and information arranged proportionally allows students to understand the historical knowledge conveyed. Many infographics provide benefits that are not provided when presenting data in a conventional manner. The human brain, since ancient times has been used to presenting various kinds of information using visuals. As evidence can be seen the many historical relics in the form of writing, which means that in ancient times the use of visual media or paintings became a form of presenting information to the public. In the modern era, education should be able to explore the potential of humans who more easily capture information combined with visuals [9], [10], rather than just text, which according to some scholars actually makes the learning situation less attractive. Through the national hero infographic, there are three units of knowledge to be conveyed to students, namely: the value of example, the spirit of bringing change, and patriotism.

This research stems from the Al-Dairy and Al-Rabaani hypothesis [11] about the importance of using infographic learning media for history learning, besides that innovative media will be easier for students to understand, because it combines information with visualgraphics. Scholars like Agustin [8], Aldila [7], Amri and Husin [12] Naparin and Saad [13] also agreed and recommended learning history that has been stigmatized so far to be able to utilize innovative media to attract students' enthusiasm in learning. The research that has been carried out totally highlights the technical use of infographics, while this research emphasizes the qualitative impact analysis of historical learning using national hero infographics, especially with regard to developing students' historical knowledge [14], [15]. These scholars have agreed to integrate the use of technology in history learning, this, in the era of pandemics and distance education, is very important, especially the use of infographics will add to the essence of innovative and enjoyable history learning.

Based on the above discussion, this study aims to analyze the development of historical knowledge of students, through history learning with national hero infographic media. This research makes an important contribution to the strengthening of history learning in the online era. This paper provides recommendations for teachers, to be able to improvise properly, especially in using technology to strengthen learning.

\section{Method}

The study used qualitative methods with descriptive designs [16]. The object of study described is the process of developing students' historical knowledge through learning history with national hero infographic media. The data source of this study came from teachers and students, at least there were 6 teachers involved in this study from high school in Semarang, while 10 students were involved. Data were collected used in-depth interview and observation techniques [17], [18]. In-depth interviews are used to uncover the process of developing students' historical knowledge through language expression [19]. Observations were made to complete the interview data, so that a complete and complete understanding of the analysis process will be obtained. Data analysis uses an interactive model. Interactive analysis model according to Miles and Huberman [20] that is, in qualitative research it is possible to do data analysis when the researcher is in the field or after returning from the field a new analysis is held. In this study data analysis has been carried out in conjunction with the data collection process. Stages of data analysis in this study are; data collection, data reduction, data 
presentation, and verification / conclusion drawing. This data analysis model provides a dynamic opportunity for researchers to complete the research data, even though they have arrived at the analysis process.

\section{Result And Discussion}

Effective and efficient learning can be achieved by using learning media [21]. The learning media holds an important position in learning activities because it becomes a medium of information distribution of lecturers to students. Many added values obtained by students when using instructional media, including: clarifying the presentation of the message so as not to be too verbalistic (in the form of mere written or oral words), overcoming limitations of space, time and senses, giving rise to enthusiasm in learning, enabling interaction more directly between students with the environment and reality, and allows students to learn themselves according to their abilities and interests [9], [22]. Media is an alternative in the learning process because students will not only get material from one source, but material from various sources selected through the stages of student needs analysis. The position of the media is certainly very important, because the media functions as an intermediary, it will be able to cover the lack of delivery of instructors in learning. National hero infographic media contains a chronological complete story and exemplary national hero figures used as content in the media. Through national hero infographic media, Aldila [7] explains that students are more enthusiastic about studying heroic attitudes and values, learning about heroes so far only tells about great narratives that are close to mythology, therefore, using infographics as a teacher is easier to present information about a hero more effectively. This also allows students to participate in the learning process enthusiastically. Informants argue:

"national hero infographic, in learning can lead to student enthusiasm, brands can dialogue with each other, this dialogue process becomes important because students view the hero as an object of knowledge, no longer a character who has no loopholes to be criticized, not infrequently students can criticize a person heroes, because they feel they don't agree with the explanation given."

One of the problems in learning history in schools lies in the supporting elements of understanding, namely textbooks. Almost all textbooks, both published by the private sector and the government, are actually not suitable for reference [23], [24]. Almost all book authors only read curriculum documents literally and are unable to understand the spirit of the curriculum well. This becomes a problem when in school, teachers are not able to manage the content of the material available in textbooks, but instead utilize the learning resources as the only one. Whereas the teacher should manage the information to be used as media, so the learning will take place dialectically, because from the beginning the teacher has provided learning resources and media independently [25]. It should be criticized that, most textbook authors for learning do not understand history as science, historiography, and lag far behind in the latest references in history writing. In this situation what should be a bridge between the needs and supply of material is the teacher who is an individual who is close to students. In the research findings, the teacher has provided a national hero infographic media that is utilized from the results of research and development conducted at the university. This media is 
prepared to make it easier for students to understand historical learning and hope students can have a historical knowledge critically. Informants argue:

"I divide students into groups, I use infographic media to provoke students, I want to see how active they are, it turns out that in praxis, they are quite active and critical to see the text and graphics presented, initially about the national hero Sukarno, now that's right many pros and cons, so it becomes more interesting and students are very enthusiastic, the sign is that the student already has critical reasoning and his sense of history has been formed."

Based on the above learning, it can be understood that the teacher uses cooperative strategies to develop students' historical knowledge. The explanation above also shows that infographic media has several advantages in developing students' historical knowledge [2], [26]. The advantages of visual communication through national hero infographics include: visualization of hero images capable of replacing explanations that are too long and too theoretical, as well as replacing the appearance of images without information that has been a display in each classroom. Through the graphical visualization of interesting data, the messages and values contained in the figure that the teacher wants to convey are more easily received attention from students. Student informants argue:

"if only text or lecture, sometimes we are bored and lazy to pay attention to the history learning process, because it is less interesting, but using infographic media, we become enthusiastic, because in infographics we don't only see letters, but there are pictures that are designed, now learning becomes more interesting, the information conveyed is also easy to understand."

National hero infographics, according to students, after learning is considered quite interesting and triggers active learning in the classroom. In observations can be seen, that students are able to participate in learning enthusiastically, in the search for information, presentations, or discussions [27], [28]. Each student has their own preferences, but what is more important is how they can carry out the process in a democratic and open manner, not justifying a single text, but rather making all the information they explore as material for further study. The infographics taught are developed through the Corel Draw application [10], this application is the most compatible and provides easy features for developing infographic media. Through complete features, the teacher easily combines information with graphics arranged in frames. Student informants explain the content scores and essence of infographics used in learning:

"in design, this is very interesting, even the explanation about Sukarno is clearer, because it is presented chronologically in fragments, not in the whole text which is very saturating, therefore it makes it interesting, I have captured Sukarno's nationalism since he studied at H.O.S. Tjokroaminoto in Surabaya until he founded the Indonesian National Party (PNI) and was involved in the proclamation of independence. The teacher and media explanation presented was very interesting, Sukarno's nationalism became clear. I can reflect and gain a lot of experience from Sukarno's life story, if I look at the information displayed in the infographic." 
Finally, the explanation above proves that the national hero infographic has advantages that make it easier for teachers to teach material about heroism. The strengths based on the learning process under study are: the teacher is easier to convey the material with the help of infographics, the combination of graphics and information in the frame makes students interested in learning the history of heroism, and the impression of learning history is not complicated. It shows progress in learning history, where the development of student knowledge takes place with the right mix of media and learning methods. Infographics are very relevant for transmitting historical knowledge to students [2], [29]. Still based on the explanation above, it can also be seen that nationalism is a factor that drives the strengthening of students' historical knowledge. Through learning with nationalism content in infographic media, students find it easier to digest the information conveyed by the teacher, in addition the teacher is more effective in delivering the material [30], [31], because the essence of the explanation has been conveyed through the media provided. This study reinforces the findings of Agustin [8], Aldila [7], Amri and Husin [12] Naparin and Saad [13] that infographic media become contextual media to teach values and knowledge about history, support Anderson's opinion, the reasons for nationalism strengthen the position of students to be optimistic about the nation's history. Nationalism is also an essential factor in making national hero infographics, in growing student awareness, about the importance of learning history and making history a source of reflection for the lives they lead. In the era of pandemics and distance education, this media is very compatible with online media that are used by teachers in teaching. The media is relevant for developing students' historical knowledge which includes historical awareness, critical attitude, and reflective in addressing historical phenomena.

\section{Conclusion}

National hero infographics are very important and relevant media for developing students' historical knowledge. This media besides being very contextual, also has a great impact, especially in growing historical awareness and reflective attitudes of students in learning. The advantage of this media so that it is contextual and relevant lies in its ease of use, the information conveyed is concise so that the teacher's explanations are complementary, the media is easy to develop, and the teacher can quickly adapt this media in the learning process undertaken. Nationalism is a major factor in the process of developing students' historical knowledge through historical learning using national hero infographic media. A strong nationalism narrative encourages students to understand the hero figure being taught. The implication of this research is that historical education more broadly needs to utilize infographic media to develop students' historical knowledge. In the context of national hero infographics, it needs to be applied at all levels of education because it gives a direct impact on the process of strengthening student enthusiasm in participating in learning history.

\section{Acknowledgement}

The researcher would like to thank the Research and Community Service Institute (LPPM) of Universitas Negeri Semarang Indonesia for funding the entire research process to the publication of the results of this study. 


\section{References}

[1] H. Susanto and H. Akmal, Media Pembelajaran Sejarah Era Teknologi Informasi (Konsep Dasar, Prinsi Aplikatif, dan Perancangannya). FKIP Universitas Lambung Mangkurat, 2019.

[2] L. A. Sutimin, "Development of Students' Knowledge of History: Acceptance and Rejection of the Indonesia-Malaysia Confrontation Narratives," Journal of Social Studies Education Research, vol. 10, no. 2, pp. 290-307, 2019.

[3] G. F. Kurniawan, W. Warto, and L. A. Sutimin, "Dominasi Orang-Orang Besar Dalam Sejarah Indonesia: Kritik Politik Historiografi dan Politik Ingatan,” Jurnal Sejarah Citra Lekha, vol. 4, no. 1, pp. 36-52.

[4] B. Anderson, Imagined communities. Routledge, 2006.

[5] S. K. Kochhar, "Pembelajaran Sejarah (terjemahan Purwanta dan Yovita Hardiati)," Jakarta: PT. Grasindo, 2008.

[6] S. S. Wineburg, "The psychology of learning and teaching history.," 1996.

[7] T. H. Aldila, A. A. Musadad, and S. Susanto, "Infografis sebagai Media Alternatif dalam Pembelajaran Sejarah bagi Siswa SMA," ANDHARUPA: Jurnal Desain Komunikasi Visual \& Multimedia, vol. 5, no. 01, pp. 141-152, 2019.

[8] N. A. Agustin, S. E. Pramono, and R. Romadi, "Pengembangan Bahan Ajar Infografis Peristiwa Gerakan 30 September 1965 dalam Pembelajaran Sejarah Indonesia di SMAN 1 Kudus Tahun Pelajaran 2016/2017," Indonesian Journal of History Education, vol. 5, no. 1, 2017.

[9] H. Mansur and R. Rafiudin, "Pengembangan Media Pembelajaran Infografis untuk Meningkatkan Minat Belajar Mahasiswa," Jurnal Komunikasi Pendidikan, vol. 4, no. 1, pp. 37-48, 2020.

[10] H. Bicen and M. Beheshti, "The psychological impact of infographics in education," BRAIN. Broad Research in Artificial Intelligence and Neuroscience, vol. 8, no. 4, pp. 99-108, 2017.

[11] H. M. Al-Dairy and A. H. Al-Rabaani, "An analytical study of research orientations for infographies applications in education," in 2017 6th International Conference on Information and Communication Technology and Accessibility (ICTA), 2017, pp. 1-5.

[12] A. Amri and H. Husin, "Konsep Desain Infografis Gedung Villa Nova Jakarta sebagai Media Pendidikan Sejarah," Jurnal Desain, vol. 4, no. 01, pp. 1-18, 2016.

[13] H. Naparin and A. B. Saad, "Infographics in education: Review on infographics design," The International Journal of Multimedia \& Its Applications (IJMA), vol. 9, no. 4, p. 5, 2017.

[14] P. L. Berger and T. Luckmann, The social construction of reality: A treatise in the sociology of knowledge. Penguin Uk, 1991.

[15] C. B. Hutchison, "Cultural constructivism: the confluence of cognition, knowledge creation, multiculturalism, and teaching," Intercultural Education, vol. 17, no. 3, pp. 301-310, 2006.

[16] J. W. Creswell and J. D. Creswell, Research design: Qualitative, quantitative, and mixed methods approaches. Sage publications, 2017.

[17] J. P. Spradley, Participant observation. Waveland Press, 2016.

[18] J. A. Ollerenshaw and J. W. Creswell, "Narrative research: A comparison of two restorying data analysis approaches," Qualitative Inquiry, vol. 8, no. 3, pp. 329-347, 2002.

[19] T. A. Van Dijk, "18 Critical discourse analysis," The handbook of discourse analysis, pp. 349371, 2001.

[20] M. B. Miles, A. M. Huberman, and J. Saldana, "Qualitative data analysis: A methods sourcebook," 2014

[21] M. Handoko, "Pengembangan media infografis untuk pembelajaran berbasis sejarah daerah menampilkan eksistensi candi Songgoriti di SMK Ardjuna 2 Malang/Moch. Tomy Handoko," PhD Thesis, Universitas Negeri Malang, 2018.

[22] M. Berson, R. Diem, D. Hicks, C. Mason, J. Lee, and T. Dralle, "Guidelines for using technology to prepare social studies teachers," Contemporary issues in technology and teacher education, vol. 1, no. 1, pp. 107-116, 2000.

[23] J. Harris, P. Mishra, and M. Koehler, "Teachers' technological pedagogical content knowledge and learning activity types: Curriculum-based technology integration reframed," Journal of research on technology in education, vol. 41, no. 4, pp. 393-416, 2009. 
[24] T. Heafner, "Using technology to motivate students to learn social studies," Contemporary Issues in Technology and Teacher Education, vol. 4, no. 1, pp. 42-53, 2004.

[25] G. F. Kurniawan, "Pembelajaran Sejarah di Kelas XI SMA Semesta Bilingual Boarding School Semarang," Historia Pedagogia, vol. 8, no. 1, pp. 68-75, 2019.

[26] R. Romadi and G. F. Kurniawan, "Pembelajaran Sejarah Lokal Berbasis Folklore Untuk Menanamkan Nilai Kearifan Lokal Kepada Siswa," Sejarah dan Budaya: Jurnal Sejarah, Budaya, dan Pengajarannya, vol. 11, no. 1, pp. 79-94, 2017.

[27] T. A. Ahmad, Pembelajaran Sejarah Dalam Perspektif Critical Pedagogy. Semarang: Historia Pedagogia, 2012.

[28] S. D. Brookfield, Developing critical thinkers: Challenging adults to explore alternative ways of thinking and acting. Jossey-Bass, 1987.

[29] R. Hallam, "Piaget and the teaching of history," Educational Research, vol. 12, no. 1, pp. 3-12, 1969.

[30] G. Rogers, "History, learning technology and student achievement: Making the difference?," Active Learning in Higher Education, vol. 5, no. 3, pp. 232-247, 2004.

[31] J. Arthur, Issues in history teaching. Routledge, 2012. 